\title{
Internal devaluation: A controversial effort for adjustment within the Euro area
}

\author{
ESZTER BOROS*
}

Institute of Finance, Accounting and Business Law, Corvinus University of Budapest, Fővám tér 8, H-1093, Budapest, Hungary

Received: March 21, 2019 • Revised manuscript received: April 05, 2020 • Accepted: June 29, 2020

(C) 2021 The Author(s)

\begin{abstract}
The euro crisis and its lessons are still not a closed chapter for economists and policy makers. The challenge to find the most appropriate ways to prevent intra-area imbalances is still on the top of the agenda. Nominal adjustment (internal devaluation) remains one of the most critical aspects of this debate. Many are indeed interested in whether austerity measures in several countries "made sense." But much more is at stake here than evaluating the past. The true question is whether the eurozone can rely on nominal adjustment to align internal economic fluctuations. This paper contributes to the answer by investigating the size of price changes and their impacts on output and trade in the wake of the euro crisis. Selecting the most appropriate variables to measure competitive outcomes, the basic idea of "expansionary contraction" is tested. We rely on a comprehensive panel of all Eurozone member states in the post-crisis years (20102017). The results suggest that flexible price levels cannot be taken for granted, and a link to competitiveness is not self-evident, either. Other channels of adjustment may prove to be more important, but scaling them up will ultimately require a sound consensus on the future architecture of the euro.
\end{abstract}

\section{KEYWORDS}

Euro area, monetary union, euro crisis, price adjustment, internal devaluation

JEL CLASSIFICATION INDICES

E31, E42, E52, F14, F15, F32, F45

\footnotetext{
*Corresponding author. E-mail: eszter.boros@uni-corvinus.hu
} 


\section{INTRODUCTION}

The euro crisis and its myriad corollaries turned into one of the most striking problems of the last decade. A key aspect of the issue is related to the euro as a common currency. Studies have extensively discussed whether the uniform monetary framework had contributed to rising intraarea imbalances leading up to the 2010-2012 crisis. While there is evidence for endogenous incentives to accumulate credit risk (Hale - Obstfeld 2014), further questions arise about the channels of adjustment. Today, years after the turmoil and several bailout packages, it is essential to evaluate the core idea underlying the policies of the EU-IMF creditors. This is key because the future of the Eurozone (EMU) largely depends on finding the most effective ways to align intra-area economic fluctuations.

After the onset of the euro crisis, the bulk of adjustment efforts was centred around "internal devaluation." This involved wage and price cuts in the crisis economies, aimed at boosting economic activity through increased price competitiveness. In other words, the wage and price adjustments were seen as the main channel to curb intra-area differences in actual output patterns. This view was indeed at the heart of the austerity policies and "reforms" prominent in the EU - IMF agenda. Slow recovery throughout the EMU and a still less favourable economic outlook for countries like Greece or Italy, however, challenge this approach and point to the need of empirical insight. Relying on panel data, this paper aims to contribute to that understanding by investigating the effectiveness of price adjustment in the EMU during and after the euro crisis (2010-2017). Two questions are posed: (1) How were prices evolving in this period? (2) What was the impact of price changes on output, with regard to export performance and import substitution?

Empirically verified answers will help policymakers take stock of the outcomes of austerity, which is still not over in some parts of the currency union. (Just to mention the most obvious example, Greece tried to renegotiate its primary surplus targets for the upcoming years with institutional creditors (Chrysolora 2020). Nevertheless, these questions go well beyond austerity in itself. They aim to check the background concept: price flexibility, i.e. the possible inherent capacity of the EMU markets to correct for macro imbalances. Results may indicate whether the euro area can rely on a kind of automatic stabilization function, attributed to price changes by standard theory.

Most studies posing similar questions focus on the special cases of one or a few Southern member states. This paper adds to the literature by taking a much more comprehensive approach. It examines all EMU members and the whole crisis- and post-crisis period to uncover the relationship between price and trade patterns. The paper is also more straightforward in terms of separating general demand effects and competitiveness, relying on a formal decomposition method used in Oblath (2010). This allows for a clear focus on substitution of goods and services, i.e., the ultimate rationale behind internal devaluation. Adjusted trade volumes and price changes are linked by the dynamic panel models.

To highlight the most important results, we found that internal devaluation was only slightly reflected in the price dynamics of the "periphery." Overall average price cuts were delayed, remained tiny, and declines were not even restricted to the most-hit countries. To put it

\footnotetext{
${ }^{1}$ The conventional term "periphery" is used to refer to Greece, Ireland, Italy, Portugal, Spain and Cyprus.
} 
otherwise, there were no substantial increases in other parts of the EMU to further encourage shifts in competitiveness. Moreover, our models did not deliver evidence on any impacts on trade.

These conclusions reinforce the policy lessons of the euro crisis. That is, flexible price levels cannot be taken for granted, and fiscal multipliers tend to be large in times of crises. The downward spiral of internal devaluation may not be reversed by competitiveness gains (i.e. output growth due to substitution). These improvements may be rather negligible, pointing to the role of non-price factors and the need for other channels of adjustment. Institutions can be a key in this respect.

The analysis is structured as follows: Section 2 reveals the theoretical background by discussing the role of prices in a monetary union. In addition, it provides a brief overview of the related empirical literature. Section 3 presents the methodology and data. Findings are explained in Section 4 which first examines the evolution of the relevant price indices (Question 1). Then it checks their impact on trade flows (Question 2). Section 5 concludes and links the findings to the policy mix of the euro area.

\section{THE ROLE OF PRICE CHANGES IN CURRENCY UNIONS - BACKGROUND AND LITERATURE}

The relationship between price changes and net exports is of particular importance in monetary unions: it affects the magnitude of risks inherent in common currencies. Monetary unions involve stability risks because the members give up their own nominal exchange rates and more broadly, own monetary policy (Mundell 1961; McKinnon 1963; Kenen 1969; De Grauwe 2012). To put it otherwise, currency unions create a trap or an impossible trinity. The trilemma states that out of exchange rate stability, monetary autonomy and financial integration, only two can be accomplished at the same time (Mundell-Fleming trilemma, see e.g., Obstfeld et al. 2005). Adopting a common currency means an irrevocably fixed exchange rate regime with free flow of capital, which in turn excludes own monetary policy. Such arrangements can have far-reaching implications even in the case of small open economies. This is because a possible channel for short-term economic adjustment (i.e., the nominal exchange rate) is explicitly ruled out in terms of intra-area relations. ${ }^{2}$ Moreover, the inescapable need for a common monetary policy stance may pose a dilemma for the central bank of the currency area.

This trap arises if actual intra-area economic fluctuations are different in directions and/or size. The problem is most salient if directions differ, i.e., there are booms and busts within the union at the same time. ${ }^{3}$ In this case, there is no optimal monetary policy for all countries.

\footnotetext{
${ }^{2}$ A single nominal exchange rate remains vis-á-vis foreign currencies. These rates continue to act as a channel for external adjustment (albeit not necessarily reflecting the needs of all members, see Nikas 2019). Nevertheless, currency unions normally include top trade partners. The larger the share of intra-area trade, the bigger the part of adjustment that has to be achieved without nominal exchange rates (Gibson et al. 2014). As internal trade accounts for more than half of the total international trade of the EMU (ECB 2013), internal adjustment is a key question for the smooth functioning of the currency union. So, in this paper, I focus on this aspect.

${ }^{3}$ Technically speaking, business cycles are not synchronised or the common currency countries are hit by asymmetric shocks.
} 
Easing would probably help tackle recession, but it would parallelly contribute to over-heatedness in the booming economies. A reverse action is also ill-suited: a tightening is only appropriate for a subset of the members, not the entire area. The stalemate is less striking, but still exists, if fluctuations are of different amplitudes. If there is an area-wide recession, but it is deeper in some regions compared to the others, the required size of monetary easing is not evident.

Monetary conditions too loose for some economies threaten with over-indebtedness and asset price bubbles. Due to the common financial framework, exposures tend to accumulate in the balance sheets of the intra-area financiers (Hale - Obstfeld 2014). This can trigger a zonelevel crisis if the endogenous incentive to pile up debts results in defaults eventually. Note also that sovereigns in a monetary union can be more vulnerable in such cases as they are perceived to be indebted in a "foreign currency" (De Grauwe 2013).

This description largely coincides with what happened in the Eurozone before and during the crisis (Giavazzi - Spaventa 2010; Krugman 2011; Schmitz - Hagen 2011; Pisany-Ferry 2012; Baldwin et al. 2015; Stiglitz 2016; Kolodko - Pastula 2018). Nonetheless, this paper does not aim to examine the roots of the euro crisis. Instead, it focuses on the post-crisis adjustment which is also constrained by the inherent problem of monetary unions. Namely, exchange rate depreciation and unilateral monetary easing are not available for the members in (deeper) crisis.

This has been a relevant problem for the Eurozone because the downturn hit some EMU countries harder than others. At first, between 2010 and 2012, the need for substantial monetary easing was general as all members suffered. But since then, there have been considerable differences in economic performance. It is true that loose monetary conditions remained necessary for the whole area (ECB 2019), but most Southern economies have been underperforming even so. Meanwhile, some core countries have been faring better, and from time to time, they tend to perceive sustained monetary easing as a danger or disadvantage (see a German perspective in Arnold 2019.) All in all, the Mediterranean economies have been in a need for any further boost even beyond the degree allowed by common monetary arrangements.

Here we arrive at the role of prices. Price changes are a possible channel to deliver such a boost. Other channels may also be available, but the standard approach of the EU - IMF packages mostly emphasized nominal (wage and price) adjustment (EC 2015). Internal devaluation ("austerity", "expansionary contraction") was a frequently used notion. The underlying argument was that wage and price cuts were equivalent to exchange rate depreciation as they created cost and price advantage identically (De Grauwe 2012). Increased exports and import substitution will then boost output, lifting the respective economies out of recession. Intra-area output and inflation gaps get closer to each other, and the central bank's dilemma is over. $^{5}$

Note that the expected impacts of internal devaluation are ultimately linked to substitution. Price cuts eventually aim to gain market shares to the detriment of other economies' products and services. That is, more exports due to a general increase in aggregate external demand (if any) cannot be considered as a result of internal devaluation. In this case, sales rise regardless of

\footnotetext{
${ }^{4}$ They cannot unilaterally grant that their legal tender will always and unlimitedly be available to repay debts.

${ }^{5}$ Examining wages would go beyond the reasonable scope of this paper. Thus, attention is focused on prices (i.e., information directly available for purchasing decisions).
} 
relative prices. By the same token, a fall in domestic aggregate demand (due to the crisis) entails a drop in imports. While this improves the current account and helps reduce debts, it is not related to price advantage, either. It is a challenge to filter out such demand effects in the empirical analysis. This section will provide insights into how different authors handle the issue. Section 3 then goes into the detail of our own approach.

It must be stressed here that the price adjustment favourably entails more than internal devaluation in the most troubled economies. Other members are expected to increase their price levels. (Or more generally, to have stronger price dynamics.) That is, they shall be willing to inflate or at least keeping their prices mostly unchanged. This is needed to share the adjustment burdens. In this respect, Stockhammer - Sotiropoulus (2014) warn that modern inflation targeting is prone to produce a deflationary bias. If low inflation targets are strictly followed, efforts for internal devaluation remain unilateral and recovery is hindered. With twice as much inflation in other parts of the area, the same price cuts would deliver results twice as quickly (Gibson et al. 2014). Stockhammer - Sotiropoulos also note that stringent rules on budget deficits and public debt (such as those in the Maastricht Treaty) reduce the chance of symmetric adjustment, too. Peers have less space for fiscal expansion which could result in more domestic inflation and a switch to imports from the depressed countries.

Note here that price adjustment can be an automatic stabilizer. Recessions are indeed expected to bring down prices even without any intervention. If this proved to be the case empirically, the euro area would be lucky to have a mechanism for short-term internal adjustment. Policies may then rightly rely on this, and cuts in pensions, public wages etc. could be short and effective episodes. Economic synchronisation with other parts of the union would quickly happen. However, this ideal case cannot be taken for granted as it was supposed in the case of the EU - IMF policies. ${ }^{6}$

Adjustment burdens are a key here because price changes have many "side effects" compared to exchange rate fluctuations. First, price adjustment typically takes more time due to short-term rigidities and price smoothing behaviour of companies (Encaoua - Geroski 1986; Krugman 2011; De Grauwe 2012; Shambaugh 2012). Policies aiming to accelerate the process can rely mostly on cuts in public spending (wages of public servants, pensions, benefits, government purchases). However, it is highly uncertain when and to what extent these cuts translate into wages and prices in the private sector.

Second, price reductions themselves are "painful." This is a further reason for their slow pace. Krugman (2011) and Stiglitz (2016) pointed out that price decreases have immediate adverse impacts at the micro level, i.e. on firms' revenues, business continuity and survival. This is connected to the procyclical nature of financial intermediation. Banks typically tighten credit conditions in times of crises. Thus, stable corporate revenues are even more crucial to retain access to financing. However, price cuts decrease revenues until a sufficient rise in sales happens (if any at all). Outstanding debts also get more burdensome as liabilities remain unchanged in nominal terms. Non-performing loans in turn further aggravate the credit crunch. Meanwhile, business customers may be discouraged to order from suppliers on the verge of bankruptcy (even if they could purchase at more favourable prices).

${ }^{6}$ See Varoufakis (2017) and Thomsen (2019) on creditors' assumptions during the Greek crisis. 
Third, this downward spiral is not constrained to the tradable sector. Price cuts must even be larger in the non-tradable sector to redirect investments to boost exports (Tressel et al. 2014). By contrast, exchange rate adjustment, in itself and directly, does not affect the nontradable sector, neither does it change instalments for debts denominated in the domestic currency.

These recessionary effects and vicious circles have prompted research to evaluate the outcome of internal devaluation in the periphery. Most authors focus on the specific experience of one or a few countries. The Spanish example is interesting as the country has apparently recovered from the crisis by achieving 3\% annual growth and current account surpluses. This has been often considered as a result of internal devaluation (Banco de España 2016). Nonetheless, Villanueva et al. (2018) draw an opposite conclusion. They found that the Spanish net exports have mostly been driven by shifts in aggregate demand, and not by relative prices. Foreign sales were indeed rising continuously between 1995 and 2017 while price competitiveness substantially varied ("the Spanish paradox"). The authors separated between demand and price effects by including explanatory and control variables in their models. They established that the relationship between exports and price changes is rather negligible. They concluded that it was the fall in aggregate domestic demand that played a decisive role in the Spanish external readjustment between 2010 and 2017.

This conclusion is supported by Uxó et al. (2014) who estimated impacts of demand and prices on trade for three Southern countries (Spain, Greece and Portugal). (They accounted for demand effects by including the respective variables in model equations, too.) Their paper finds a significant (negative) relationship between export/import ratios and prices only for Spain. Meanwhile, demand turns out to be significant for all three countries. The authors therefore concluded that "if there had been no fall in domestic demand in Greece, Portugal and Spain, the rapid correction of the current account deficit would not have happened. (...) All this query the idea that internal devaluation may trigger an export-led resumption of growth in the periphery (...). In addition, the relationship between the adjustment of the external deficit and falling demand leads us to believe that once domestic demand recovers external imbalances could reappear" (Uxó et al. 2014: 17).

Findings of Kersan-Škabić (2016) and Malliaropulos - Anastasatos (2013) further reinforce this insight. The former author suggests that the EU - IMF programs produced questionable results in terms of growth outcomes. The latter study also draws attention to the "side effects" of these reform packages, especially for Greece. The authors do not only point to the fact that external readjustment was due to a general collapse in aggregate demand, but also stress impacts on the real economy. They observe that internal devaluation motivated "the survival of labourintensive low technology specializations."

Even institutional creditors (mostly from the IMF) acknowledge that certain measures cost more in terms of GDP than previously anticipated (Thomsen 2019). However, the overall approach has not been discredited by these organizations, and failures are primarily explained by a lack of deep structural reforms and political commitment on the part of the "program countries." So, despite a kind of consensus in the literature on the ineffectiveness of Southern internal devaluation episodes, this debate is far from over. This paper should thus provide a relevant contribution to the ongoing EMU overhaul including a search for the most appropriate ways of the intra-area adjustment. 


\section{METHODOLOGY AND DATA}

The challenge to find the right methodology for the purposes of this paper is threefold. The ultimate focus, i.e., modelling the impact of price changes on trade flows, namely requires at least three specific considerations.

1. The first is about dependent variables: how to measure "true" trade performance regarding intra-EMU exports and imports, with effects of aggregate demand filtered out.

2. The second consideration is about the most important explanatory variables, i.e., price changes. This again raises the question of measurement: which price indices should be taken into account and how. These variables will be used to answer the first research question about how prices evolved in the EMU during and after the crisis. Price changes will then be inserted as independent variables in the respective models.

3. The third point involves control variables. Non-price factors are needed which may contribute to the competitive edge of products and services of an economy (or the lack of it).

A further consideration certainly relates to the modelling approach. Dynamic panel models best fit this research as they allow to examine multiple individuals and years in a single data set. This analysis includes 17 EMU countries $(i)$ and 8 years $(t)$ since the onset of the euro crisis (20102017), yielding 136 observations $(N)$ for each variable. ${ }^{7}$ This composition is in line with the focus on the intra-EMU adjustment. Dynamic models are built to capture time patterns as well.

\subsection{Dependent variables: Adjusted exports and imports}

As discussed previously, the key results of internal devaluation are to be achieved through substitution. That is, products and services of a country undergoing this process are expected to sell better both in export and domestic markets, to the detriment of foreign competitors and independently of actual patterns of aggregate demand. ${ }^{8}$ Demand effects are often accounted for by control variables, such as in Villanueva et al. (2018) and Uxó et al. (2014). Alternatively, market shares are considered (Malliaropulos - Anastasatos 2013).

Our paper takes a different approach: impacts of demand on trade are filtered out even before estimating the models. Adjusted trade volumes are produced by decomposition equations based on Oblath (2010). These formulas provide corrective terms both for exports and imports separately which can be used to re-calculate original time series of trade flows for each country. This method provides advantages compared to a pure analysis of aggregate market shares or controlling only for aggregate demand. Those approaches do not allow to get rid of a bulk of demand and composition effects. ${ }^{9}$ This decomposition, however, is a more advanced "filter." It accounts for both general and partial shifts in demand, with regard to the composition of exports and imports.

\footnotetext{
${ }^{7}$ Malta and Luxembourg are omitted due to their size and lack of data. 2018 is not included due to data gaps.

8 "Economy" and "country" are henceforth used as synonyms. Competition is interpreted at the country level.

${ }^{9}$ It can be shown that the aggregate market share of a seller might increase even if its market shares are unchanged in all submarkets. This is the case if sales are concentrated on products/services for which demand outperforms the change in aggregate demand. In other words, aggregate market shares may indicate better performance in a misleading way.
} 
3.1.1. Adjusted exports. As regards exports, the decomposition relies on Eq. (1):

$$
\begin{aligned}
& \Delta x_{i, t}=x_{i, t-1} \frac{\Delta M_{t}}{M_{t-1}}+\mathrm{GD}(\mathrm{ex})_{i, t} \sum_{j=1}^{J}\left[x_{i, j, t-1}\left(\frac{\Delta M_{j, t}}{M_{j, t-1}}-\frac{\Delta M_{t}}{M_{t-1}}\right)\right]+\sum_{j=1}^{J}\left[x_{i, j, t-1}\left(\frac{\Delta x_{i, j, t}}{x_{i, j, t-1}}-\frac{\Delta M_{j, t}}{M_{j, t-1}}\right)\right] \\
& \operatorname{STR}(\mathrm{ex})_{i, t} \\
& \mathrm{XC}_{i, t}
\end{aligned}
$$

$x_{i, t}$ denotes the aggregate intra-EMU export volume of country $i$ in year $t$. Equation (1) decomposes the annual absolute change in this volume $\left(\Delta x_{i, t}\right)$. The change is attributed to three factors.

First, "general demand effect" (GD(ex) $\left.)_{i, t}\right)$ shows that to what extent $x_{i, t}$ would have increased or decreased in year $t$ due to a change in demand of foreign EMU markets exclusively. Demand is captured by the overall worldwide imports $\left(M_{t}\right)$ of EMU peers. (As this paper focuses on internal adjustment, EMU peers are taken into account as the target market for exports. Their general demand is best reflected, however, by their total imports).

Second, "structural effect" (STR $\left.(e x)_{i, t}\right)$ also reflects the impact of demand, but with regard to export composition. Index $j$ namely refers to the product groups and services whose demand may change differently from the aggregate shift. Demand is measured by the EMU peers' worldwide imports of the respective product group, denoted by $M_{j, t}{ }^{10} \mathrm{STR}_{i, t}$ is relevant because composition and demand effects jointly produce additional expansion or contraction in exports, on top of general demand effects. Note that if country $i$ mostly exports product group $j$ in year $t-1$, and foreign demand for $j$ then outperforms aggregate demand, foreign sales of country $i$ will expand more. Thus, $\mathrm{STR}_{i, t}$ shows to what extent intra-EMU exports $\left(x_{i, t}\right)$ would have changed due to different patterns in demand and export composition, exclusively. Such a change is still not related to substitution.

Substitution is captured by the third term, called "export competitiveness effect" $\left(\mathrm{XC}_{i, t}\right)$. This component is a key for this paper as it is used to correct time series of exports for each country (Eq. (2)). $\mathrm{XC}_{i, t}$ shows to what extent intra-area exports would have increased or fallen due to changes in market shares in the internal market. $\mathrm{XC}_{i, t}$ indicates a rise only if growth in the EMU sales outperforms the change in demand in a sufficient range of different submarkets. ${ }^{11}$ It must be underlined here that within the context of this paper, internal devaluation can be regarded as effective only if higher values of $\mathrm{XC}_{i, t}$ are achieved.

$\mathrm{XC}_{i, t}$ is used to adjust time series of exports for each country $\left(\operatorname{AdjExp}_{i, t}\right)$ Eq. (2):

$$
\operatorname{AdjExp}_{i, t}= \begin{cases}\mathrm{NDA} & \text { if } t=1 \\ \operatorname{OrigExp}_{i, t-1}+\mathrm{XC}_{i, t} & \text { if } t=2 \\ \operatorname{AdjExp}_{i, t-1}+\mathrm{XC}_{i, t} & \text { if } t>2\end{cases}
$$

OrigExp $_{i, 1}$ stands for the initial data in the original time series (i.e., data for 2009 in this case).

\footnotetext{
${ }^{10} M_{t}=\sum_{j=1}^{J} M_{j, t}$ and $x_{i, t}=\sum_{j=1}^{J} x_{i, j, t}$

${ }^{11}$ Note that $\mathrm{XC}_{i, t}$ is positive only if market shares grow in at least one submarket. (In contrast, a higher aggregate market share would still be possible with unchanged shares in all submarkets. So, that variable could mislead us. It is true that $\mathrm{XC}_{i, t}$ is higher if the exporter boosts the shares of its top exported products and services. Nevertheless, this can be regarded as a rather acceptable remaining "bias" because specialisation in itself mostly stems from a sustained competitive advantage. (And a bulk of composition effects have already been separated through $\mathrm{STRi}_{, t}$.)
} 
The subsequent dynamics of AdjExp ${ }_{i, t}$ only reflect the impact of changing competitive positions in the internal market. In other words, $\operatorname{AdjExp}_{i, t}$ shows the amount of exports which would have been sold by country $i$ in the euro area, should there have been no change in demand at all. A key aim of internal devaluation is to achieve higher values of $\operatorname{AdjExp}_{i, t}$. Adjusted exports are used in the respective panel model as the dependent variable (see Section 4.3).

To produce $\operatorname{AdjExp}_{i, t}$, data on trade in products were retrieved from Eurostat's Easy Comext (E-Comext) database. As for product groups, BEC classification was available for use. ${ }^{12}$ Fuels and lubricants (BEC3) and other products not elsewhere classified (BEC7) as trade in these goods were omitted because either they were highly dependent on exogenous factors (e.g. world oil prices) or data were missing for them. Thus, trade flows used to quantify $\mathrm{XC}_{i, t}$ and $\mathrm{Adj}_{\mathrm{Exp}} \mathrm{E}_{i, t}$, cover food and beverages (BEC1), industrial supplies (BEC2), capital goods and parts and accessories thereof (BEC4), transport equipment and parts and accessories thereof (BEC5), consumer goods (BEC6) and services. ${ }^{13}$ For the latter, the Eurostat's tables on trade in services were used. All trade flows are volumes, produced by using original data in current prices and chainlinked volume indices. (All indices were retrieved from the same data sources and for the respective trade flows. As regards services, volumes were calculated by relying on the Eurostat's index for service producer prices [SPPI].)

To grasp how adjusted exports evolved, Fig. 1 shows the annual average growth rates of $\operatorname{AdjExp}_{i, t}$ for different groups of the member countries.

The Southern and Irish periphery suffered a sharp decrease in its adjusted exports in 2012, which was primarily driven by a fall in Greek and Cypriot sales. This could be due to the massive uncertainty about the "survival" of these economies at the height of the euro crisis when even a Greek exit was in the cards. After 2012, the periphery slightly increased its adjusted exports in every year. That is, their products and services could gain some additional market shares enough for a rise in aggregate sales volumes. Nevertheless, the annual average growth was rather small, with a minimum rate of $0.15 \%$ for the Mediterranean countries in 2015 (the year of the third phase of the Greek crisis). It was only Cyprus which achieved sustained and stronger increases, with rates staying above 5\% in the wake of the 2012 crash.

In average terms, the tiny values of the periphery are similar to those of the Eastern members, while mostly outweigh the growth rates of the core. The core members, especially Austria, Belgium, France and Germany registered negative rates, i.e., decreases in their adjusted exports, in three subsequent years between 2014 and 2016. Putting simply, their exporters were losing out to foreign competitors in the internal market. To some extent, these competitors must have included the Mediterranean and Irish sellers (as they had meanwhile positive rates as just highlighted). This vague observation raises the question whether the shift was due to price changes (internal devaluation in the periphery), and/or what kind of other factors could have an impact. The results will follow in Section 4.3.

3.1.2. Adjusted imports. Regarding imports, our approach is the same. A corrective term to produce adjusted imports is given by the following decomposition equation (Eq. (3)):

\footnotetext{
${ }^{12}$ BEC: Broad Economic Categories.

${ }^{13}$ All trade volumes in this paper include services and BEC product groups as listed here. Data sources for trade flows are the same throughout the paper.
} 


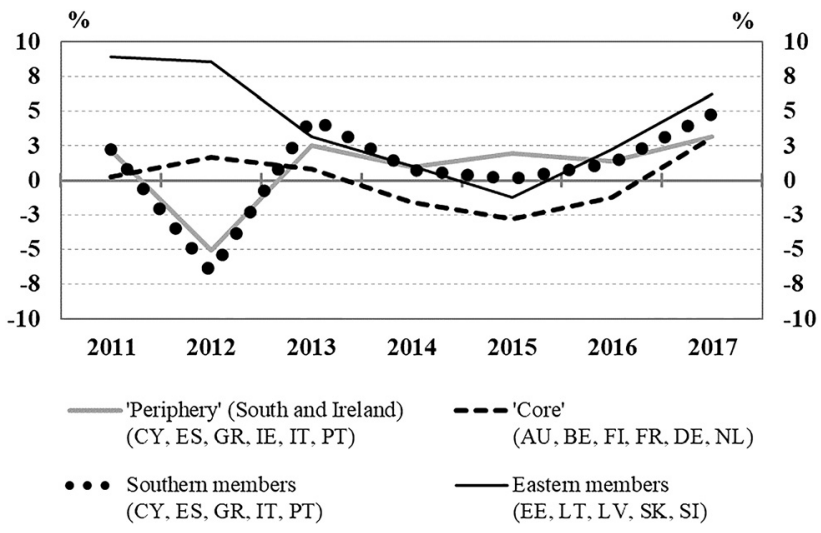

Fig. 1. Annual average growth rates of intra-EMU adjusted exports for different groups of member countries

Note: Unweighted averages of first differences of $\log \left(\operatorname{Adj}_{\operatorname{Exp}}, t\right)$ of the respective countries, expressed in \%. Source: Author's own calculations.

$$
\begin{aligned}
\Delta m_{i, t}= & m_{i, t-1} \frac{\Delta F_{i, t}}{F_{i, t-1} \mathrm{GD}(\mathrm{im})_{i, t}}+\sum_{k=1}^{K}\left[m_{i, k, t-1}\left(\frac{\Delta F_{i, k, t}}{F_{i, k, t-1}}-\frac{\Delta F_{i, t}}{F_{i, t-1}}\right)\right]_{\mathrm{STR}(\mathrm{im})_{i, t}} \\
& +\sum_{k=1}^{K} m_{i, k, t-1}\left(\frac{\Delta m_{i, k, t}}{m_{i, k, t-1}}-\frac{\Delta F_{i, k, t}}{F_{i, k, t-1}}\right)_{\mathrm{MS}_{i, t}}
\end{aligned}
$$

This time, aggregate imports from the euro area $\left(m_{i, t}\right)$ are examined. The annual absolute change $\left(\Delta m_{i, t}\right)$ again results from three different factors.

First, the impact of shifts in aggregate demand $\left(\mathrm{GD}(\mathrm{im})_{i, t}\right)$ is identified. As the domestic market of country $i$ is relevant here, demand is captured by the country's own aggregate domestic use $\left(F_{i, t}\right)$. This includes final consumption expenditures of households and gross capital formation, or simply, consumption and investment. Data on $F$ were downloaded from Eurostat. $\mathrm{GD}(\mathrm{im})_{i, t}$ shows to what extent imports from the EMU would have been increased or fallen in country $i$ in year $t$, due to a change in its own aggregate demand exclusively.

Second, there is again a "structural effect" $\left(\operatorname{STR}(\mathrm{im})_{i, t}\right)$. This accounts for the fact that domestic demand for certain categories of products and services $(k)$ could change differently, and the resulting impact depends on import composition. If country $i$ is a large importer of $k$, but its demand for this category $\left(F_{i, k, t}\right)$ drops sharply, aggregate imports will likely plummet. Such a fall does not, however, follow from import substitution. Thus, STR has to be disregarded when producing adjusted imports. ${ }^{14}$ I used different COICOP categories and gross capital formation to specify $F_{i, k, t}$ to best match the classification of products and services. ${ }^{15}$

\footnotetext{
${ }^{14}$ Note that $m_{i, t}=\sum_{k=1}^{K} m_{i, k, t}$ and $F_{i, t}=\sum_{k=1}^{K} F_{i, k, t}$.

${ }^{15}$ COICOP: Classification of individual consumption by purpose. For reasons of consistency, $k=j=\mathrm{BEC} 1, \mathrm{BEC} 2$, BEC4, BEC5, BEC6, services. Details of the matching are available from the author on request.
} 
Third, a change in $m_{i, t}$ due to competition is captured by "import substitution effect" $\left(\mathrm{MS}_{i, t}\right)$. This component is a key in this paper as it is used to produce adjusted imports (Eq. (4)). $\mathrm{MS}_{i, t}$ is positive if import growth outperforms domestic use for a sufficient range of $k$ categories. This namely means that the intra-EMU imports gained market shares in country $i$ to the detriment of other producers, including domestic ones. In contrast, a negative $\mathrm{MS}_{i, t}$ indicates an intra-area import substitution. So, within the context of this paper, any internal devaluation can be considered as effective only if it comes with negative values of MS.

$\mathrm{MS}_{i, t}$ is used to adjust time series of imports for each country (AdjImp $\left.{ }_{i, t}\right)$ (Eq. (4)):

$$
\operatorname{AdjImp}_{i, t}= \begin{cases}\text { NDA } & \text { if } t=1 \\ \text { OrigImp }_{i, t-1}+\mathrm{MS}_{i, t} & \text { if } t=2 \\ \operatorname{AdjImp}_{i, t-1}+\mathrm{MS}_{i, t} & \text { if } t>2\end{cases}
$$

OrigImp $_{i, 1}$ denotes the initial data in the original time series (data for 2009). Based on this, a correction for demand and composition effects happens for each year. The resulting time series reflects only the impact of competition. Import substitution (providing a chance for inland producers to boost sales) occurs if $\mathrm{AdjImp}_{i, t}$ decreases. Note that internal devaluation shall come with such a decline. Whether this was the case in the EMU is investigated in Section 4.4, where I use $\operatorname{AdjImp}_{i, t}$ as the dependent variable in the respective panel equation.

Let us take a look at the annual average growth rates of AdjImp ${ }_{i, t}$ for country groups. Fig. 2 shows that the core slightly increased its adjusted EMU imports throughout the whole period. To put it otherwise, domestic producers in Austria, Belgium, Germany, Finland, France and the Netherlands could have lost out to competitors from other parts of the currency area. This may be in line with the fact that the periphery and the Eastern countries were able to slightly raise their adjusted exports in average terms (remember Fig. 1).

Fig. 2 does not reveal a clear pattern for the Southern countries and Ireland. There is no sign of a considerable setback for imports from the EMU. This is partly different for Cyprus which saw significant declines in its adjusted imports in 2011-2012, 2015 and 2017. The Eastern members are more similar to the core in this case as they increased imports in most years.

Figs. 1 and 2 together suggest that the members embarking on internal devaluation (the Mediterranean countries and Ireland) could have achieved some competitive advantage against EMU "rivals" in the internal market at least in some years. This observation is further examined in Section 4.4 while the remaining sections here describe the explanatory variables.

\subsection{Independent variables 1: Price changes}

As we intend to focus on internal devaluation most directly, we choose annual average changes to measure the degree of price adjustment. Yearly price indices are designed to exactly match the respective trade flows described in the previous section.

3.2.1. Export prices. The annual price index (XP) for the intra-EMU exports is calculated for country $i$ in year $t$ as follows (Eq. (5)).

$$
\mathrm{XP}_{i, t}=\frac{\sum_{\mathrm{BEC}}\left(q_{\mathrm{BEC}, i, t}^{\mathrm{EX}} * I_{\mathrm{BEC}, i, t}^{\mathrm{EX}}\right)+q_{\mathrm{serv}, i, t}^{\mathrm{EX}} * \mathrm{SPPI}_{i, t}}{\left(\sum_{\mathrm{BEC}} q_{\mathrm{BEC}, i, t}^{\mathrm{EX}}\right)+q_{\mathrm{serv}, i, t}^{\mathrm{EX}}}
$$

$\mathrm{XP}$ reveals the annual average change in prices of products and services exported to the euro 


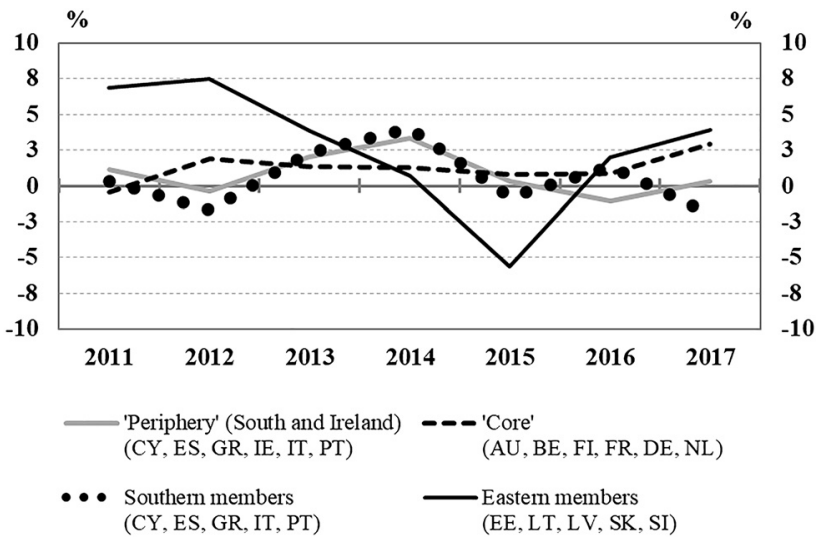

Fig. 2. Annual average growth rates of intra-EMU adjusted imports for different groups of member countries

Note: Unweighted averages of first differences of $\log \left(\operatorname{Adj}_{\mathrm{Imp}} \mathrm{m}_{i, t}\right)$ of the respective countries, expressed in \%. Source: Author's own calculations.

area. Changes in price levels of different groups of exported products are measured by $I_{\mathrm{BEC}, i, t^{\mathrm{EX}}}{ }^{16}$ For services exports, no dedicated price index is available. So, we use $\mathrm{SPPI}_{i, t}$. It shows the annual average change in the service producer prices in country $i$, and as such, it might be a proxy for changes in the price level of services exports. ${ }^{17} I_{\mathrm{BEC}, i, t}^{\mathrm{EX}}$ and $\mathrm{SPP} I_{i, t}$ are used to calculate a weighted average. Weights reflect the composition of intra-EMU sales; $q^{\mathrm{EX}}$ namely denotes the respective export volumes in year $t$.

In case of internal devaluation, $\mathrm{XP}_{i, t}$ is certainly expected to be less than $100 \%$ (or more generally, to remain below the indices of other economies). The evolution of XP in different country groups is discussed in Section 4.1 .

3.2.2. Import prices versus domestic prices. In terms of imports, the difference between foreign and domestic price dynamics $\left(D_{i, t}\right)$ is the most relevant for these purposes. This is calculated according to Eq. (6):

$$
D_{i, t}=I_{i, t}^{\mathrm{IM}}-I_{i, t}^{\mathrm{dom}}
$$

\footnotetext{
${ }^{16}$ Index BEC covers BEC1, BEC2, BEC4, BEC5 and BEC6. To quantify $I_{\mathrm{BEC}, i, t}^{\mathrm{EX}}$, I was able to resort to unit value indices (UVIs) in the E-Comext. Using the most detailed breakdown of products, UVIs are based on elementary unit value indices (EUVIs). EUVIs measure the annual average change in trade value per quantity. UVIs are weighted averages of EUVIs and are well-suited to approximate the change in price levels.

${ }^{17}$ However, it must be stressed that SPPI only covers services as required by the European Union's Regulation on ShortTerm Statistics (1165/98/EC and amendments known as "STS Regulation"). Thus, SPPI does not account for hotels and restaurants which is a considerable limitation. In addition, note that Eurostat provides chain-linked indices $(2010=100 \%)$ in all cases. Annual indices were derived following Keresztély et al. (2008).
} 
$I_{i, t}^{\mathrm{IM}}$ shows the annual average change in prices of the intra-EMU aggregate imports of country $i$ in year $t$. It is calculated by using Eq. (7):

$$
I_{i, t}^{\mathrm{IM}}=\frac{\sum_{\mathrm{BEC}}\left(q_{\mathrm{BEC}, i, t}^{\mathrm{IM}} * I_{\mathrm{BEC}, i, t}^{\mathrm{IM}}\right)+q_{\mathrm{serv}, i, t}^{\mathrm{IM}} * \mathrm{SPPI}_{-} \operatorname{avg}_{i, t}}{\left(\sum_{\mathrm{BEC}} q_{\mathrm{BEC}, i, t}^{\mathrm{IM}}\right)+q_{\mathrm{serv}, i, t}^{\mathrm{IM}}}
$$

Similarly to XP, this is a weighted average of changes in price levels of imported products and services. For product groups, price changes are measured by $I_{\mathrm{BEC}, i, t}^{\mathrm{IM}}$. For services, shifts in prices are proxied by the average SPPI of EMU peers (SPPI_avg $\left.{ }_{i, t}\right)$. Weights $\left(q^{\mathrm{IM}}\right)$ correspond to intraarea import volumes of the respective product groups and services in year $t$.

$I_{i, t}^{\text {dom }}$ denotes the annual average change in domestic producer prices. We choose producer prices to "match" import prices because both are measured at similar stages of the supply chain (i.e., before entering retail trade). $I_{i, t}^{\text {dom }}$ accounts for changes in producer prices of products $\left(\mathrm{PPII}_{i, t}\right)$ and services $\left(\mathrm{SPPI}_{i, t}\right)$. According to Eq. (8), it is a weighted average of the respective indices. Weights are equal to ratios in domestic gross value added $\left(v a_{i, t}\right)$. Note that PPII stands for producer price index in industry, being the only suitable index available.

$$
I_{i, t}^{\mathrm{dom}}=\frac{v a_{i, t}^{\mathrm{ind} *} \mathrm{PPII}_{i, t}+v a_{i, t}^{\text {serv } *} \operatorname{SPPI}_{i, t}}{v a_{i, t}^{\text {ind }}+v a_{i, t}^{\text {serv }}}
$$

$D_{i, t}$ is positive if $I_{i, t}^{\mathrm{IM}}$ exceeds $I_{i, t}^{\mathrm{dom}}$, i.e., price dynamics of imports outweigh those of domestic production. In case of internal devaluation, this should be indeed the case. The evolution of $D$ in different country groups is discussed in Section 4.2 .

\subsection{Independent variables 2: Control variables}

Control variables are needed to capture non-price effects. For reasons of consistency, we collected variables which fit in both of our models. In other words, these variables may have an impact both on export competitiveness and import substitution. The selection is based on several papers (Altomonte et al. 2012; Cardoso et al. 2012; Correa-López - Doménech 2012; Esteves - Rua 2013; Malliaropulos - Anastasatos 2013; Karadeloglou - Benkovskis 2015; Giordano - Zollino 2016; Xifré 2017). Most of these authors argue that non-price factors are crucial (or even more important than prices) in explaining competitive outcomes. Thus, it is indirectly suggested that impacts of internal devaluation on output may be limited, possibly even in the short run.

The final set of control variables was created by checking proper availability of data in Eurostat's database. So, we ended up with 7 variables:

1. Proportion of small enterprises ( $<50$ employees) based on turnover $\left(\%\right.$, SmallEnt $\left._{i, t}\right)$,

2. Proportion of foreign-controlled enterprises based on turnover $\left(\%\right.$, ForEnt $\left._{i, t}\right)$,

3. Gross fixed capital formation (\% of GDP, $\mathrm{GFCF}_{i, t}$ ),

4. Research and development (R\&D) expenditures (\% of GDP, $\mathrm{RD}_{i, t}$ ),

5. Enterprises' total turnover from e-commerce (\% of turnover, EComm $\mathrm{E}_{i, t}$ ), 
6. Industrial concentration of gross value added (Herfindahl-Hirschman index, Indust ${ }_{i, t}$ ),

7. EMU trade openness: intra-area exports and imports as a \% of GDP $\left(\operatorname{TradeOp}_{i, t}\right){ }^{18}$

Based on the literature of competitive advantage, we might have the following expectations regarding the impact of these variables.

As for small enterprises, a higher ratio of them might come with less competitiveness. ${ }^{19}$ This may be due to limited or no access to export markets and certain sales channels or less innovation, less resources for marketing, few recognisable brand names or falling short of quality standards and consumers' expectations. Regarding foreign-controlled enterprises, there are mixed expectations. A higher ratio must involve stronger participation in international supply chains. On the one hand, this may contribute to better competitive positions in export markets, but on the other hand, it may encourage imports.

More GFCF and R\&D spending are expected to proxy better qualitative features of products and services, and as such, they might come with more adjusted exports and less adjusted imports. In addition, a higher ratio of e-sales can be coupled with stronger competitive positions in all markets. As regards domestic industrial concentration, outcomes are rather uncertain. More specialization can be either a source and sign of competitive advantage or a barrier to expand market shares in various markets.

In case of the EMU trade openness, there are mixed expectations again, similar to the ratio of foreign-controlled enterprises. On the one hand, more intra-area trade linkages may facilitate expansion in export markets, due to a well-established access to sales channels and trust between international partners. On the other hand, this may also support the inflow of imports, and thus, probably less import substitution.

For brevity, no detailed descriptive statistics are presented here. ${ }^{20}$ The "big picture" of these variables suggests that the Mediterranean economies are rather closed, having rather few intraarea trade linkages and foreign-controlled firms. They are also rather fragmented in terms of company size and industrial distribution. Moreover, their investments and innovation capacities lag behind their peers. All in all, the Southern region is a quite homogenous one in terms of the control variables, while countries of the core and Eastern region exhibit more various values.

\section{EMPIRICAL ANALYSIS}

This Section first outlines price changes, namely the evolution of XP and $D$ (Sections 4.1 and 4.2). This is to investigate to what extent internal devaluation involved price cuts in the South, and whether there was a symmetric adjustment entailing stronger price dynamics elsewhere in

\footnotetext{
${ }^{18}(1),(2)$ and (5) exclude the financial sector. In case of (2), all foreign countries of the world are taken into account. (5) covers enterprises with at least 10 employees. (6) entails all economic activities, with higher HHI values (up to 10,000) indicating higher concentration. (7) refers to trade in BEC1, BEC2, BEC4, BEC5, BEC6 and services. Variables are either calculated by the author based on Eurostat data or retrieved directly from Eurostat.

19"Less competitiveness" is used here to shortly refer to unfavourable outcomes in adjusted exports (a decrease or a negligible increase) and/or unfavourable outcomes in adjusted imports (an increase or a negligible decline).

${ }^{20}$ Information is available from the author on request.
} 
the EMU (Question 1). Then, the impact of price changes on adjusted exports and imports is tested by the respective panel models (Question 2, Sections 4.3 and 4.4).

\subsection{Changes in intra-EMU export prices}

Averages of XP for country groups are presented in Fig. 3.

It is striking that all regions follow the same pattern. This is attributed to the fact that every EMU member was hit by the crisis, at least to some extent. More generally, the co-movement in Fig. 3 reflects the high level of integration of these economies. So, between 2012 and 2016, all regions were characterised by tiny average price changes as regards intra-area exports. This is true for most countries separately as well. It is only Cyprus which had average changes (cuts) amounting to $-3-5 \%$ in two years. As for increases, no country surpassed $3 \%$ in any years.

Although minor, cross-sectional differences still offer some insights. The Mediterranean countries displayed the most moderate price dynamics on average. Their values are exceeded by the core in each year and also by the Eastern region in most years. Generally, this reflects the efforts for internal devaluation in the Southern periphery. Even a more moderate price dynamics may have been enough to contribute to a competitive edge in the internal market (or alternatively, to narrow a competitive disadvantage). Whether there was a significant overall link, is tested in Section 4.3.

Note, however, that the actual price cuts remained limited. First, decreases were considerably delayed after the outbreak of the euro crisis, and they were mostly constrained to 2 years (2013 and 2014). Second, they were not restricted to the Southern periphery as other countries also registered some cuts. (In fact, it was only Germany, Austria, Estonia and surprisingly, Italy which had no XP values below 100\%.) Third, the overall size of cuts was tiny as already discussed. These all point to the relevance of burdens that internal devaluation imposes on firms (Section 2). The second observation also highlights that there was no symmetric price adjustment in the sense that price levels did not increase substantially in any parts of the area. (Not

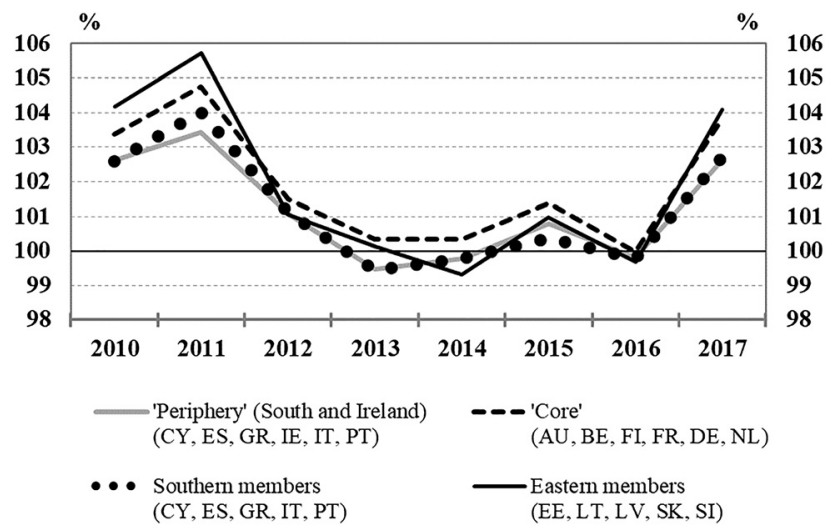

Fig. 3. Annual average change in prices of exported products and services (sold within the euro area) for different groups of member countries (XP index) Note: Unweighted averages of $\mathrm{XP}_{i, t}$ of the respective countries, expressed in $\%$. Source: Author's own calculations. 
even in countries which were faring relatively better in the aftermath of the crisis.) All of these insights raise further questions on the pricing behaviour of firms, which, however, go beyond the scope of this paper.

\subsection{Changes in the difference between price indices of intra-EMU imports and domestic production}

Fig. 4 shows the averages of $D$ for country groups. (Remember that $D$ is positive if imports have stronger price dynamics, i.e., a higher increase or a smaller decrease.)

There is an overwhelming majority of positive values in every group. This implies, in general, that the crisis and the subsequent stagnation hit domestic producers more severely throughout the euro area, compared to those selling abroad. This is in line with the previous observations that cuts in export prices remained limited. The fact that domestic producers were more exposed to downward price pressures may be attributed to the different characteristics of the respective markets. Companies selling abroad may be integrated in international supply chains. These ensure a more stable demand and possibly a financial "safety net" as well. These firms may also have a stronger market power due to their size and product differentiation (e.g., recognisable brand names). Although these factors are not examined in this paper in terms of pricing, they are controlled for when investigating price effects on imports (Section 4.4).

Similarly to XP, domestic price cuts were delayed in the Southern and Irish periphery. (Average producer prices increased by more than 2.5\% in Cyprus in 2011-2012, and at least by $3.5 \%$ in Greece and Spain in 2011, just to mention the most salient examples.) Internal devaluation kicked in in 2013, and up until 2016, the periphery was having the largest positive $D$ s in average terms within the union. This was achieved by actual cuts in the Mediterranean countries. Declines were most articulated in Cyprus $(-3.2 \%$ as an annual average). The other Southern countries had annual average cuts exceeding $1 \%$. Meanwhile, price indices of imports were increasing or stagnating in these countries.

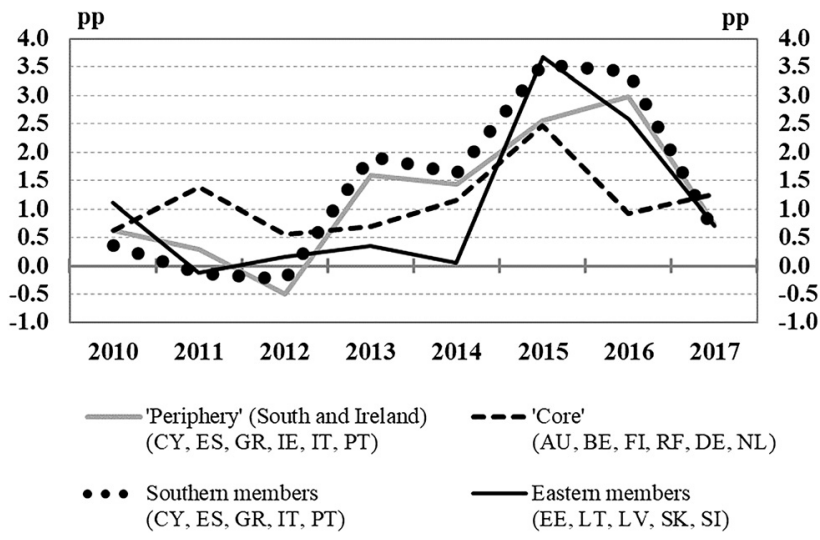

Fig. 4. Annual average difference between price indices of intra-EMU imports and domestic production for different groups of member countries $(D)$

Note: Unweighted averages of $D_{i, t}$ of the respective countries, expressed in percentage points.

Source: Author's own calculations. 
All of these mean that decreasing nominal revenues became reality for a substantial part of domestic producers in the Mediterranean region. (Even if this was preceded by price hikes up until 2012, and the subsequent cuts were not huge on average.) Depending on the ratio of imported inputs, producers faced a relatively stronger cost dynamics at the same time. This difficult situation provided some chance for an increased import substitution. Whether such a link existed is examined in Section 4.4.

Fig. 4 offers further insights into the possible role of the other regions. To achieve a truly symmetric adjustment, negative $D$ s would have been expected in the core (i.e., stronger domestic price dynamics in order to "give way" to intra-EMU imports). This did not happen as growth and spending remained moderate in these countries. So, there were no or limited incentives for core customers to switch to foreign products. There was a similar pattern in the Eastern region.

\subsection{Relationship between adjusted exports and price changes}

Now we examine Question 2 about the impact of price changes on intra-area trade. Panel models consist of elements specified in Section 3, and they are estimated by using the generalized method of moments (GMM), based on Arellano - Bond (1991). The GMM estimator is applied to avoid inconsistent estimates which would result from a parallel use of dynamic models and fixed effects (Balázsi et al. 2014; Kiss et al. 2019). GMM estimation implies that individual effects cancel out (Croissant - Millo 2008).

For all variables, first differences of logarithms are used, except for XP and $D$. These two variables are applied in their original form; there is only a slight modification to XP in which case the actual percentage change is used (instead of an index). All abbreviations are meant henceforth accordingly, i.e., they denote logarithmic differences, except for XP and D. Logarithmic differences allow us to interpret variables as annual growth rates. Furthermore, this transformation is widely used to produce stationary time series. Thus, it is a reasonable assumption that these variables are stationary. ${ }^{21}$

Against this background, the panel model for adjusted exports takes the following general form (Eq. (9)):

$$
\operatorname{AdjExp}_{i, t}=\rho \operatorname{AdjExp}_{i, t-1}+\sum_{m=1}^{M} \beta_{m} x_{i, t-1, m}+\sum_{m=1}^{M} \gamma_{m} x_{i, t, m}+\varepsilon_{i, t}
$$

where $m$ is the number of independent variables $\left(x_{m}\right)$ covering XP and the seven control variables $(m=1,2, \ldots, 8)$. The model includes lagged and contemporaneous values for them. A further explanatory variable is provided by the lag of the dependent variable (AdjExp). $\varepsilon_{i, t}$ denotes the error term.

Estimation results are presented in Table 1.

The lag of AdjExp has not proved to be significant. It is thus suggested that the previous year's export performance is not indicative for the present. A preceding expansion in market shares does not "grant" new successes (enough to boost aggregate intra-area exports further). This result is likely to point to a high degree of competition within the internal market. There is

\footnotetext{
${ }^{21}$ No formal test was carried out due to the length of time series ( $t=6$ when considering differences and lags). The rather short period is in fact a limitation to the dynamic modelling. This note also applies to the next section.
} 
Table 1. Panel model for adjusted exports

\begin{tabular}{|c|c|c|c|}
\hline \multicolumn{4}{|c|}{ Dependent variable: AdjExp } \\
\hline Independent variables & Coefficient & Std. error & $P$-value \\
\hline lag (AdjExp) & -0.260 & 0.636 & 0.684 \\
\hline lag (XP) & 2.560 & 1.029 & $0.012 *$ \\
\hline XP & 1.121 & 0.842 & 0.183 \\
\hline lag (SmallEnt) & 2.251 & 1.453 & 0.121 \\
\hline SmallEnt & 0.793 & 0.987 & 0.422 \\
\hline lag (ForEnt) & 0.036 & 0.200 & 0.856 \\
\hline ForEnt & -0.247 & 0.246 & 0.314 \\
\hline lag (GFCF) & 0.281 & 0.084 & $0.001 * *$ \\
\hline GFCF & 0.208 & 0.205 & 0.311 \\
\hline lag (RD) & 0.039 & 0.131 & 0.763 \\
\hline RD & 0.350 & 0.154 & $0.024^{*}$ \\
\hline lag (EComm) & 0.036 & 0.047 & 0.444 \\
\hline EComm & -0.088 & 0.082 & 0.280 \\
\hline lag (Indust) & -1.323 & 0.622 & $0.033^{*}$ \\
\hline Indust & 1.625 & 1.035 & 0.116 \\
\hline lag (Trade0p) & -1.068 & 1.260 & 0.396 \\
\hline Trade0p & 1.153 & 0.245 & $2.462 \mathrm{e}-06 * * *$ \\
\hline \multicolumn{4}{|c|}{ Sargan test: $\mathrm{Chi}-\mathrm{sq}(20)=-1.590 \mathrm{e}-14(P$-value $=1)$} \\
\hline \multicolumn{4}{|c|}{ Wald test for coefficients: Chi-sq(17) $=991.160(P$-value $=<2.22 \mathrm{e}-16)$} \\
\hline \multicolumn{4}{|c|}{ Square of correlation between AdjExp and estimated AdjExp: 0.096} \\
\hline \multicolumn{4}{|c|}{ Initial number of observations $(N)=136, i=17, t=8$, No. of observations used $\left(N^{\prime}\right)=102$} \\
\hline
\end{tabular}

Notes: Significance: $* * * 0 ; * * 0.01 ; * 0.05$.

Coefficients significant at $\alpha \leq 5 \%$ are written in bold. For abbreviations, refer to Section 3.3.

Source: Author's own calculations.

a favourable interpretation for this in terms of price adjustment: when needed, the members may more easily gain new market shares, irrespective of their existing positions.

This opportunity could be underscored by lag(XP). The previous year's average change in export prices has namely proved to be significant. However, the result is not in line with the logic of internal devaluation as the estimated coefficient is positive. The best interpretation here thus suggests that competitive positions are not hurt by the stronger annual price dynamics. Conversely, price cuts are not expected to result in higher export volumes. That is, even if Figs. 1 
and 3 could suggest some negative relationship between adjusted exports and price dynamics, this is not reflected by a comprehensive panel of the EMU members. This outcome may well be an alert for policies that base intra-area adjustment solely on downward price pressures. The conclusion is in line with Villanueva et al. (2018), Kersan-Škabić (2016), and essentially, with Uxó et al. (2014) as well. Furthermore, it underlines the relevance of non-price factors as highlighted by many authors listed earlier.

The significance of non-price variables is explicitly reflected in the output, too. There are namely four control variables that have proved to be significant: gross fixed capital formation, $\mathrm{R} \& \mathrm{D}$ spending, industrial concentration and EMU trade openness. Results suggest that the higher the ratio of investments (GFCF) in the previous year, the stronger growth is achieved in adjusted exports. ${ }^{22}$ The same positive relationship holds for the ratio of $\mathrm{R} \& \mathrm{D}$ expenditures. These outcomes coincide with our preliminary expectations. More investments and innovation are likely to result in a higher perceived value for customers. The fact that the Mediterranean countries typically had lower ratios throughout the period, may highlight a barrier that hindered stronger growth in their adjusted exports.

As regards industries, a negative coefficient supports the interpretation that a higher concentration of economic activities comes with a subsequent decrease in export growth. More specialization may hamper the ability to expand market shares in a sufficient range of submarkets. As the Mediterranean countries were mostly characterized by lower HHIs, this factor should not have been decisive in their quite modest export performance. However, the opposite seems true in terms of trade openness. The Southern economies had smaller ratios of EMU trade which could be a severe disadvantage. Trade openness has namely turned out to be significant at any conventional levels, and has a positive coefficient. A lower degree of trade openness thus implies a decline in the growth rate of adjusted exports.

Finally, note that the ratio of small enterprises, foreign-controlled enterprises and e-sales are not significant in this model. In addition, the explanatory power of the model is low (9.6\%) which points to the relevance of further non-price factors.

To conclude, our results deliver no evidence that price adjustment was effective in boosting exports in the wake of the euro crisis. Policies that solely rely on prices to "trigger an export-led resumption of growth" in any parts of the area may well need a re-consideration (Uxó et al. 2014: 17). Enhancing investments, innovation, diversification and export orientation should then be a key to find ways to a better functioning currency union.

\subsection{Relationship between adjusted imports and price changes}

In the same spirit, the panel model for adjusted imports is given by Eq. (10):

$$
\operatorname{AdjImp}_{i, t}=\tau \operatorname{AdjImp}_{i, t-1}+\sum_{m=1}^{M} \kappa_{m} x_{i, t-1, m}+\sum_{m=1}^{M} \lambda_{m} x_{i, t, m}+\varepsilon_{i, t}
$$

here, $m$ again equals to 8 , with $x_{m}$ comprising $D$ and the seven control variables. Estimation results are presented in Table 2.

\footnotetext{
${ }^{22}$ All such explanations are meant as ceteris paribus expectations throughout the paper.
} 
Table 2. Panel model for adjusted imports

\begin{tabular}{|c|c|c|c|}
\hline \multicolumn{4}{|c|}{ Dependent variable: AdjImp } \\
\hline Independent variables & Coefficient & Std. error & $P$-value \\
\hline lag (AdjImp) & 2.463 & 1.110 & $0.027^{*}$ \\
\hline $\operatorname{lag}(D)$ & 0.003 & 0.003 & 0.213 \\
\hline$D$ & 0.001 & 0.005 & 0.784 \\
\hline lag (SmallEnt) & 3.070 & 1.514 & $0.043^{*}$ \\
\hline SmallEnt & -0.473 & 0.418 & 0.258 \\
\hline lag (ForEnt) & 0.264 & 0.297 & 0.374 \\
\hline ForEnt & -0.157 & 0.251 & 0.531 \\
\hline lag (GFCF) & 0.066 & 0.078 & 0.394 \\
\hline GFCF & -0.413 & 0.134 & $0.002 * *$ \\
\hline lag (RD) & -0.346 & 0.147 & $0.018 *$ \\
\hline RD & -0.049 & 0.056 & 0.400 \\
\hline lag (EComm) & 0.108 & 0.048 & $0.026 *$ \\
\hline EComm & -0.109 & 0.071 & 0.121 \\
\hline lag (Indust) & 0.458 & 0.462 & 0.321 \\
\hline Indust & -0.741 & 0.347 & $0.033^{*}$ \\
\hline lag (Trade0p) & 0.255 & 0.643 & 0.692 \\
\hline Trade0p & -1.010 & 0.752 & 0.179 \\
\hline \multicolumn{4}{|c|}{ Sargan test: $\mathrm{Chi}$-sq(20) $=2.178 \mathrm{e}-13(P$-value $=1)$} \\
\hline \multicolumn{4}{|c|}{ Wald test for coefficients: Chi-sq(17) $=1804.775(P$-value $=<2.22 \mathrm{e}-16)$} \\
\hline \multicolumn{4}{|c|}{ Square of correlation between Adjlmp and estimated Adjlmp: 0.02\% } \\
\hline \multicolumn{4}{|c|}{ Initial number of observations $(N)=136, i=17, t=8$, No. of observations used $\left(N^{\prime}\right)=102$} \\
\hline
\end{tabular}

Notes: Significance: $* * * 0 ; * * 0.01 ; * 0.05$.

Coefficients significant at $\alpha \leq 5 \%$ are written in bold. For abbreviations, refer to Section 3.3.

Source: Author's own calculations.

This time, the lag of the dependent variable (AdjImp) has proved to be significant. So, contrary to the case of exports, the competitive position of imports is influenced by preceding developments in the domestic market. If growth in the intra-area adjusted imports accelerated in the previous year, the same can be expected in the present. This possibly signals the deteriorating situation of domestic producers in several countries during the crisis. As many firms went bankrupt or struggled to survive and scaled down employment and production (especially in the periphery), market shares could have been taken over by imports year by year. Thus, the 
significant positive coefficient of lag(AdjImp) might reveal the prevalence of the downward spiral, rather than the stimulating effects, of internal devaluation.

This is further underlined by the fact that $D$ has turned out insignificant. So even though domestic producers generally faced higher pressure on their prices (Section 4.2, Fig. 4), a more moderate price dynamics was not coupled with less adjusted intra-EMU imports. As shown in Fig. 2, there were indeed no clear and/or robust patterns of import substitution. So, again, the comprehensive panel of the EMU countries suggests that price adjustment was not effective to boost output in the aftermath of the euro crisis. This result resonates well with Villanueva et al. (2018) and Uxó et al. (2014). These authors concluded that in the Mediterranean countries, a fall in aggregate imports was almost exclusively due to demand. That is, the main channel of internal devaluation was a general shrinkage in demand, and not import substitution.

Sustained market shares of imports may then be attributed to non-price factors. In our analysis, five of them have proved to be significant: the ratio of small enterprises, gross fixed capital formation, $\mathrm{R} \& \mathrm{D}$ expenditures, the ratio of e-commerce sales and industrial concentration. Results show that the higher the share of small firms in the preceding year, the stronger the growth of adjusted imports. This outcome is in line with the preliminary expectations. It points to the possible constraints of small enterprises in terms of production volume, productivity, product quality and variety. Note that the ratio of small companies was higher in the Mediterranean countries which could thus hinder import substitution.

GFCF and lag(RD) are significant likely for the same reasons as in our previous model. More investments and resources for innovation come with a slower growth (decline) in adjusted imports as domestic products and services meet higher standards.

Two interesting outcomes are related to e-commerce and industrial distribution. Contrary to expectations, the higher the ratio of domestic firms' revenues from e-commerce, the more vivid the growth in adjusted imports. This variable may act here as a proxy for digital economy. That is, a more widespread use of online channels "opens up" the market for imports. In contrast, a higher concentration of activities has turned out to come with a slowdown in adjusted imports. This is a controversial result which may point to the role of clusters. Specialisation may facilitate the formation of complete inland supply chains.

Note that the ratio of foreign-controlled enterprises and EMU trade openness has not proved to be significant in this model. Despite six significant variables, the explanatory power of the model still remains considerably low.

To sum up, this section has not delivered evidence on the impact of price changes, either. However, it has again reflected the relevance of non-price factors.

\subsection{Limitations}

Certain limitations of this paper follow from methodological and data issues, common for research on trade competitiveness. The study could only resort to short time series, so the number of observations in the panel could not be extended further. The aim was to draw conclusions on impacts of price changes. However, the actual size of price changes in this sample was rather tiny. It is of course uncertain how estimates would change in case of vast price movements. To put it otherwise, the relationship between price changes and trade may not be linear. A connected issue is the role of price levels. This paper focused exclusively on price changes. Furthermore, our models highlighted the significance of non-price factors, but reached 
limited explanatory power. This must be related to difficulties of capturing and measuring such factors, aggravated by a scarcity of data. Finally, it was beyond the scope of this paper to investigate impacts on extra-EMU trade.

\section{CONCLUSIONS}

This paper examined the outcomes of price adjustment in the euro area in the aftermath of the crisis. It aimed to answer two questions: first, how prices were actually changing in this period, and second, whether the observed price dynamics had an impact on intra-area exports and imports of the EMU countries. These questions test the basic idea of the EU - IMF crisis management policies, i.e., the distinguished role of nominal adjustment (internal devaluation). Our research is not only relevant for evaluating the past, but it aims to contribute to a better functioning currency union in the future. It is namely imperative to identify the most effective channels of the short-term intra-area adjustment, bearing in mind the constraints of a single monetary policy.

While many papers have been written with a similar focus, this study adds to the literature by examining a comprehensive panel of the EMU countries for the whole crisis and post-crisis period (2010-2017). First, it establishes that average price changes of the intra-EMU exports remained tiny, even in the case of the Southern and Irish periphery which was facing the most severe downturn and austerity policies. Price cuts were a bit more pronounced in the domestic markets, with inland producers being less able to resist downward price pressures. Nonetheless, price decreases were not constrained to the periphery. In sum, the Mediterranean price levels did not considerably underperform those of other EMU regions. So, internal devaluation mostly remained a theoretical concept as a general downward rigidity of price levels kicked in. Moreover, there was little "support" in the form of price increases in the member countries faring relatively better.

Second, price changes have not proved to influence export performance and import substitution. Although market shares were apparently "on the move", favouring the periphery in some years, the comprehensive panel has not delivered evidence on a relationship with the pricing patterns. However, several non-price factors have turned out to be significant, first of all gross fixed capital formation and R\&D spending.

The key conclusion of this paper is the controversial nature of "expansionary contraction", i.e., the idea of austerity-based nominal adjustment. This finding implies that policies to promote price flexibility are questionable as well. Measures to strengthen (cross-border) competition, dismantle entry barriers, raise price transparency and price awareness are all standard "recipes" in this respect, and they have also been applied by the EU and IMF creditors in the "program countries." As a matter of fact, these steps have mainly proved to be counterproductive (or ill-designed, at best). In most cases, they resulted in higher vulnerability of domestic producers, instead of facilitating an effective price advantage.

Our results suggest that such structural reforms must be more comprehensive, i.e., going beyond a narrow focus on nominal rigidities. Steps for a more integrated internal market and stronger competition may well remain on the agenda, but a more complex view of competitiveness is required. Policies shall be targeted at scaling up investments and $\mathrm{R} \& \mathrm{D}$ activities in the first place. 
As regards the short-term intra-area adjustment, the importance of other channels shall be acknowledged, too. This entails the role of institutions and the financial system. Reforms such as the banking union, the macroeconomic imbalance procedure and macroprudential tools may prove to perform better than price adjustment in terms of preventing imbalances. For such an outcome, the single most important milestone is a sound ideological and policy consensus which the member states should reach on the future architecture of the euro.

\section{REFERENCES}

Altomonte, C. - Aquilante, T. - Ottaviano, G. (2012): The Triggers of Competitiveness. Bruegel Blueprint Series, 17, Brussels: Bruegel.

Arellano, M. - Bond, S. (1991): Some Tests of Specification for Panel Data: Monte Carlo Evidence and an Application to Employment Equations. Review of Economic Studies, 58(2): 277-297.

Arnold, M. (2019): Draghi Faces Chorus of Criticism over Fresh Stimulus. Financial Times Online, 13 September 2019.

Balázsi, L. - Divényi, J. K. - Kézdi, G. - Mátyás, L. (2014): A közgazdasági adatforradalom és a panelökonometria (The Revolution in Economic Data and Panel Econometrics). Közgazdasági Szemle, 61(11): 1319-1340.

Baldwin, R. - Beck, T. - Bénassy-Quéré, A. - Blanchard, O. - Corsetti, G. - De Grauwe, P. - den Haan, W. - Giavazzi, F. - Gros, D. - Kalemli-Ozcan, S. - Micossi, S. - Papaioannou, E. - Pesenti, P. - Pissarides, Ch. - Tabellini, G. - Weder di Mauro, B. (2015): Rebooting the Eurozone. Step I. Agreeing on a Crisis Narrative. CEPR Policy Insight, No. 85, (November).

Banco de España (2016): Annual Report 2015. Downloaded: December 10, 2018, https://www.bde.es/bde/ en/secciones/informes/Publicaciones_an/Informe_anual/index2015.html.

Cardoso, M. - Correa-López, M. - Doménech, R. (2012): Export Shares, Price Competitiveness and the 'Spanish Paradox'. Vox CEPR Policy Portal, 24 November 2012, https://voxeu.org/article/export-sharesprice-competitiveness-and-spanish-paradox. Downloaded: March 3, 2019.

Chrysolora, E. (2020): IMF Backs Greece's Primary Surplus Case. Ekathimerini, 12 January 2020 http:// www.ekathimerini.com/248315/article/ekathimerini/business/imf-backs-greeces-primary-surplus-case. Downloaded: January 16.

Correa-López, M. - Doménech, R. (2012): The Internationalisation of Spanish Firms. BBVA Research Working Papers, No. 12/30 (December 2012).

Croissant, Y. - Millo, G. (2008): Panel Data Econometrics in R: The plm Package. Journal of Statistical Software, 27(2): 1-43.

De Grauwe, P. (2012): Economics of Monetary Union. (9th ed.) Oxford: Oxford University Press.

De Grauwe, P. (2013): Design Failures in the Eurozone - Can They Be Fixed? European Economy, Economic Papers, 491 (April). European Commission, Brussels.

Encaoua, D. - Geroski, P. (1986): Price Dynamics and Competition in Five OECD Countries. OECD Economic Studies, 6: 47-76.

Esteves, P. S. - Rua, A. (2013): Is There a Role for Domestic Demand Pressure on Export Performance? ECB Working Paper Series, No. 1594 (September 2013).

European Central Bank (2013): Intra-Euro Area Trade Linkages and External Adjustment. ECB Monthly Bulletin, January: 59-74. 
European Central Bank (2019): Press Release about 12 September 2019 Decisions of the Governing Council. 12 September 2019. Downloaded: November 6, 2019, https://www.ecb.europa.eu/press/pr/date/2019/ html/ecb.mp190912 08de50b4d2.en.html.

European Commission (2015): Quarterly Report on the Euro Area. European Economy 14(1). DG for Economic and Financial Affairs, Brussels.

Eurostat Easy-Comext (without date of publication): Metadata on Unit Value Indices. http://epp.eurostat. ec.europa.eu/newxtweb/ Downloaded: November 15, 2018.

Giavazzi, F. - Spaventa, L. (2010): Why the Current Account May Matter in a Monetary Union. Lessons from the Financial Crisis in the Euro Area. IGIER Working Paper Series, No. 426. Innocenzo Gasparini Institute for Economic Research.

Gibson, H. D. - Palivos, T. - Tavlas, G. S. (2014): The Crisis in the Euro Area: An Analytic Overview. Journal of Macroeconomics, 39: 233-239.

Giordano, C. - Zollino, F. (2016): Shedding Light on Price- and Non-Price-Competitiveness Determinants of Foreign Trade in the Four Largest Euro-Area Countries. Review of International Economics, 24(3): 604-634.

Hale, G. - Obstfeld, M. (2014): The Euro and the Geography of International Debt Flows. Federal Reserve Bank of San Francisco Working Paper Series, No. 2014-10 (December).

Karadeloglou, P. - Benkovskis, K. (eds) (2015): Compendium on the Diagnostic Toolkit for Competitiveness. ECB Occasional Paper Series, No. 162 (July 2015), European Central Bank.

Kenen, P. B. (1969): The Theory of Optimum Currency Areas: An Eclectic View. In: Mundell, R. Swoboda, A. (eds): Monetary Problems of the International Economy. Chicago: University Press of Chicago, pp. 41-60.

Keresztély, T. - Cserháti, I. - Takács, T. (2008): A láncolás kezelése az idősormodellekben (Chain-Linking in Time Series Models). Statisztikai Szemle, 86(12): 1126-1142.

Kersan-Škabić, I. (2016): Is Internal Devaluation Policy in the EU Effective? Economic Annals, 61(211): 2946.

Kiss, G. D. - Csiki, M. - Varga, J. Z. (2019): Comparing the IMF and the ESM through Bond Market Premia in the Eurozone. Public Finance Quarterly, 2019(2): 277-293.

Kolodko, G. - Postula, M. (2018): Determinants and Implications of the Euro Enlargement. Acta Oeconomica, 68(4): 477-498.

Krugman, P. (2011): Can Europe Be Saved? New York Times Magazine, 16 January 2011, p. 26.

Malliaropulos, D. - Anastasatos, T. (2013): The Improvement in the Competitive Position of the Greek Economy and Prospects for an Export-Led Growth Model. Eurobank Research Economy and Markets, $8(1)$.

McKinnon, R. I. (1963): Optimum Currency Areas. The American Economic Review, 53(4): 717-725.

Mundell, R. A. (1961): A Theory of Optimum Currency Areas. The American Economic Review, 51(4): 657665.

Nikas, C. - Stoupos, N. - Kiohos, A. (2019): The Euro Area: Does One Currency Fit All? International Review of Applied Economics, 33(5): 642-658.

Oblath, G. (2010): Magyarország "feltárult" nemzetközi versenyképessége közép-kelet-európai összehasonlításban (Hungary's International Competitiveness in Comparison with Central and Eastern Europe). In: Kolosi, T. - Tóth, I. G. (eds): Társadalmi Riport 2010 (Social Report 2010). Budapest: TARKI Social Research Institute, pp. 192-212. 
Obstfeld, M. - Shambaugh, J. C. - Taylor, A. M. (2005): The Trilemma in History: Trade-Offs Among Exchange Rates, Monetary Policies and Capital Mobility. Review of Economics and Statistics, 87(3): 423-438.

Pisani-Ferry, J. (2012): The Known Unknowns and the Unknown Unknowns of the EMU. Bruegel Policy Contribution, No. 2012/18.

Schmitz, B. - Hagen, V. J. (2011): Current Account Imbalances and Financial Integration in the Euro Area. Journal of International Money and Finance, 30(8): 1676-1695.

Shambaugh, J. C. (2012): The Euro's Three Crises. Brookings Papers on Economic Activity, 43(1): 157-231.

Stiglitz, J. E. (2016): The Euro. How a Common Currency Threatens the Future of Europe. New York: W. W. Norton \& Company.

Stockhammer, E. - Sotiropoulos, D. P. (2014): Rebalancing the Euro Area: The Costs of Internal Devaluation. Review of Political Economy, 26(2): 210-233.

Thomsen, P. M. (2019): The IMF and the Greek Crisis: Myths and Realities. Speech by Thomsen, P. M., Director of the European Department of the IMF at the London School of Economics (30 September 2019). https://www.imf.org/en/News/Articles/2019/10/01/sp093019-The-IMF-and-the-Greek-CrisisMyths-and-Realities. Downloaded: March 1, 2020.

Tressel, T. - Wang, S. - Kang, J. S. - Shambaugh, J. C. - Decressin, J. - Brooks, P. K. (2014): Adjustment in Euro Area Deficit Countries: Progress, Challenges, and Policies. IMF Staff Discussion Notes, No. 14/7, 2014.

Uxó, J. - Paúl, J. - Febrero, E. (2014): Internal Devaluation in the European Periphery: The Story of a Failure. UCLM Working Paper, DT 2014/2.

Varoufakis, Y. (2017): Adults in the Room. My Battle with the European and American Deep Establishment. New York: Farrar, Straus and Giroux.

Villanueva, P. - Cárdenas, L. - Uxó, J. - Álvarez, I. (2018): The Role of Internal Devaluation on the Correction of the Spanish External Deficit. Instituto Complutense de Estudios Internacionales Working Papers, WP 05/2018.

Xifré, R. (2017): Non-Price Competitiveness Factors and Export Performance: The Case of Spain in the Context of the Euro Area. Spanish Economic and Financial Outlook, 6(3): 55-66.

Open Access. This is an open-access article distributed under the terms of the Creative Commons Attribution 4.0 International License (https://creativecommons.org/licenses/by/4.0/), which permits unrestricted use, distribution, and reproduction in any medium, provided the original author and source are credited, a link to the CC License is provided, and changes - if any - are indicated. (SID_1) 